\title{
ORGANIZING CLERICAL WORKERS: DETERMINANTS OF SUCCESS
}

\author{
RICHARD W. HURD and ADRIENNE MCELWAIN*
}

\begin{abstract}
This paper investigates factors influencing the outcome of union organizing efforts among clerical workers in the private sector. Drawing on interviews with union officials involved in clerical organizing campaigns, the authors analyze NLRB data on elections held in 1979. They find that the percentage of clerical workers voting yes in representation elections was related positively to the strength of the union presence in the state and employment growth in the industry, and negatively to the level of strike activity in the state and management resistance to unionization. The delay between the filing of an election petition and the holding of the election had no significant effect on the vote.
\end{abstract}

W ITH employment declining in those industries where unions have traditionally been strongest, unions must expand their presence in sectors of the economy where employment is growing in order to avoid further declines in membership and influence. Most of the expanding industries are in the service sector, where clerical workers account for a majority of employment. Labor leaders are aware of the importance of responding to the changing economy. In a 1984 AFL-CIO seminar, for example, several speakers called for increased organizing activity among women workers in white-collar occupations. The most notable proponent of this position was Thomas Donahue, secretary-treasurer of the national AFLCIO (Bureau of National Affairs 1984:77).

* Richard Hurd is Associate Professor and Adrienne McElwain is Assistant Professor, both in the Whittemore School of Business and Economics, University of New Hampshire. The authors are grateful to the University of New Hampshire Faculty Development Grant Program for financial support. They also thank Jill Kriesky and Denise Blaha for research assistance.
Academic researchers have explored some aspects of the challenge facing the labor movement as it attempts to organize the service sector. Several studies have explored the impact of gender on expressed interest in unionization or on the outcome of union certification elections (see, for instance, Antos, Chandler, and Mellow 1980; Lawler and Hundley 1983). Although results are mixed, most analysts conclude that women workers are at least as likely as men to support unionization (Stephen and Kaufman 1986; Farber 1985). Some researchers have moved beyond the question of gender to explore the unionization potential of workers in specific occupations and industries. Most of these studies have compared broad categories of workers, such as white-collar workers and blue-collar workers (Maranto and Fiorito 1987). None of the published research has investigated directly the factors that influence support for unionization among workers in the clerical occupations. This study is an attempt to fill that void. 
Professional research on union organizing in recent years has focused on the results of union certification elections conducted by the National Labor Relations Board. Most of the research has attempted to statistically explain election results for a specific time period based on aggregate data (see Heneman and Sandver 1983 for a summary of the research). Following a similar approach, this study uses election data for 1979 to estimate a model of the outcome of NLRB elections in units of clerical workers. Although some of the independent variables were selected based on prior research on NLRB elections, others were generated from interviews with organizing directors and organizers from unions particularly active among clerical workers. This reliance on interviews with union organizers sets this study apart from previous research.

\section{The Organizer Interviews}

In order to gain a better understanding of the factors affecting the outcome of NLRB elections involving clerical units, interviews were conducted in 1985 and 1986 with national and local union officials with relevant organizing experience. ${ }^{1}$ Although only ten interviews are cited below, the picture that emerges is based on more than fifty interviews with representatives from eight national unions involved in private sector clerical organizing: the Teamsters, the Service Employees, the Communications Workers, the Food and Commercial Workers, the Office and Professional Employees, the Auto Workers, the International Brotherhood of Electrical Workers, and the Hotel Employees.

Specific organizing techniques vary considerably from one union to another, but there are a few principles that seem to be accepted by most clerical organizers. The

\footnotetext{
${ }^{\mathrm{I}}$ Interview schedules are available from the authors on request. We interviewed union organizers rather than management representatives because it was easy to locate organizers with extensive experience in clerical campaigns, whereas management representatives are unlikely to specialize in responding to clerical worker organizing campaigns.
}

organizers portray clericals as very cautious and thorough when considering whether to support an organizing campaign. Personal contact with these workers is especially important. To facilitate a personalized approach, the organizing committee is typically quite large, consisting of 10 percent or more of the proposed unit. Most organizing takes place during small meetings over lunch. Union meetings after work are avoided because clerical workers often have responsibilities at home to which they must attend.? Although organizers vary in the degree of emphasis they place on written communication, all agree that newsletters or flyers in clerical campaigns must be prepared with careful attention to style, grammar, and appearance because clerical workers' skills and the demands of their jobs make them sensitive to such matters (Kushner 1986; Lechow 1985; Margolies 1986; Rahke 1986; Saporta 1986; Schaffer 1985).

Organizers sometimes target selected groups of clerical workers, and occasionally even mount advertising campaigns to attract interest, but most organizing occurs in response to inquiries from workers. Contrary to the impression given by press reports about a few high-visibility clerical locals, "women's issues" are seldom central to a clerical organizing campaign. Although many clerical organizers are eager to promote issues such as child care or pay equity, private sector clericals do not typically view their workplace concerns from a feminist perspective. In fact, traditional trade union issues predominate in most clerical organizing campaigns (Hill 1985; Margolies 1986; Saporta 1986; Schaffer 1985). Further, as is true for other types of workers, union organizing among clerical workers is most likely to succeed where the workers suffer arbitrary and unfair treatment or economic neglect by management (Margolies 1986; Nussbaum 1986; Schaffer 1985).

Although the organizers interviewed agree that private sector clerical workers

\footnotetext{
${ }^{2}$ For a case study of the clerical organizing campaign at Yale University, which typifies this approach, see Hurd 1986.
} 
are open to unionization, they view clerical organizing as very slow in comparison to organizing among other types of workers, and they do not expect dramatic membership gains among these workers in the short run. Three main reasons are cited for this opinion.

First, the personalized organizing approach described above is more timeconsuming than traditional plant gate leafleting supplemented by mass union meetings and rallies. Second, because most clericals are women who have, in varying degrees, accepted the subservient role implicit in their jobs, more attention must be given to building self-confidence than in campaigns among other groups of workers. Third, clericals typically have little prior personal experience with unions, and tend to view them as institutions dominated by angry groups of male employees. It takes time to build confidence and break down stereotypes, and frequently some type of educational program must be integrated into the organizing campaign in order to accomplish these objectives (Kushner 1986; Ladin 1985; Nussbaum 1986; Rahke 1986; Saporta 1986; Schaffer 1985).

The biggest barriers to organizing private sector clerical workers all relate to fear-fear of job loss, fear of strikes, and fear of being ostracized by fellow workers or management. Being on friendly terms with management is more important to clericals than to most other workers, because clerical workers typically interact regularly with management as part of their job. Fear of strikes is also more prevalent among clericals than among other workers. This fear usually stems either from a misunderstanding of unions and how the decision to strike is made or from a desire to work out differences amicably in order to maintain a congenial working environment. Fear of job loss may be based on the fear of being fired for union activity or it may reflect familiarity with major layoffs by unionized employers in the industry or local area (Kazel 1986; Kushner 1986; Margolies 1986; Nussbaum 1986; Saporta 1986).

Union avoidance consultants are present in most elections and play on the fears of clericals in their campaigns (Kazel 1986; Nussbaum 1986; Rahke 1986). The consultants use legal challenges to delay elections in order to obstruct the organizing campaign. Although it takes longer for unions to lay the groundwork for elections in clerical units, once a petition has been filed the organizing committee expects the process to move quickly; delays create frustration and hurt morale (Kushner 1986; Nussbaum 1986; Saporta 1986).

Where workers are already familiar with unions, union avoidance campaigns flounder, fear is less of a problem, and the organizing process is speeded up considerably. Knowledge of unions can come from any of several sources: other employees at the same workplace may be represented by a union, unions may have a strong presence in the community, family members or close friends may have experience with unions, or the employees who are objects of the organizing drive may themselves have prior personal involvement in a union (Hill 1985; Kushner 1986; Margolies 1986; Nussbaum 1986; Rahke 1986; Saporta 1986; Schaffer 1985). ${ }^{3}$

The interviews with organizers highlight some potentially important factors influencing the outcome of union representation elections among clerical workers. As explained below, several of the hypotheses suggested by the interviews are similar to those tested in prior research on union certification elections in non-clerical units. Other hypotheses, however, either have not been tested previously or at least

\footnotetext{
${ }^{3}$ Although the interviews focused on organizing among private sector clerical workers, the organizers made frequent observations comparing private sector campaigns with public sector campaigns. Public sector campaigns are widely viewed as less difficult for unions for several reasons: opposition from management is not as stiff and management consultants are not as common; access to workers on the job is more open; organizing proceeds more quickly, and the intensive personalized organizing approach is less likely to be necessary; and because of legal limitations on public sector strikes, the fear of strikes is not a major issue. Some organizers specifically observed that in the near future unions will focus on public sector clerical organizing because it is less difficult (Margolies 1986; Nussbaum 1986; Rahke 1986).
} 
take on new meaning because the interviews suggest explanations that differ from those offered in prior studies.

\section{Empirical Model}

Studies of union certification elections typically either analyze the individual's decision to vote for or against representation or analyze the election itself. Because our goal is a better understanding of the factors affecting the outcome of a union certification election among clerical workers, we adopt the election-level focus. The outcome of an election can be specified either as the proportion of voters who vote for union representation or as a win-lose dichotomous variable. We examine a percent-vote model in the belief that this specification reveals more about the election outcome than does a simple dichotomous specification. In addition, the factors that are hypothesized to influence the decision to vote for or against union representation may significantly affect the proportion of individuals voting for the union without altering the election outcome.

We have chosen to classify the factors influencing the outcome of a union certification election into three categories: variables related to worker interest in unionization, variables related to management resistance to unions, and miscellaneous election and bargaining unit characteristics. Each of these categories is discussed below. Table 1 presents definitions and data sources.

\section{Variables Related to Worker Interest in Unionization}

Level of unionization. The level of unionization in the state is included because nonunion workers can be expected to be more open to unionization in states where unionization is firmly established than in other states. Seeber and Cooke (1983) have demonstrated a significant positive relationship between the level of unionization in a state and the union victory rate in elections among all types of workers, and the interview results lead us to expect the same to hold for clerical workers. Seeber and Cooke define the variable as the percentage of workers organized in the state in which the election is held. We define a variable in this manner but we also explore the impact of an alternative measure of the level of unionization: the number of locals in the state per thousand employed. We feel that a worker's awareness of unions in a state may be more a function of the number or "saturation" of locals in the state than of the percentage of workers who are unionized. That is, the amount of publicity unions enjoy may hinge more on the number of locals than on the number of union members.

Labor movement vitality. Because unionization is not common among clerical workers, they are likely to be particularly influenced by the vitality of the labor movement in their local area. If the labor movement is growing in their area, the prospect of unionization should be more appealing. If the labor movement is shrinking in their area, the prospect of unionization may appear not only less attractive, but even threatening.

As in the case of defining level of unionization variables, for labor movement vitality we use two measures: the change from 1975 to 1980 in the percentage of the labor force that was unionized in the state, and the change in the number of locals per thousand employed in the state. We believe the latter is the better measure. The number of union members may change due to the expansion or contraction of employment in unionized workplaces independent of any action on the part of organized labor. A change in the number of locals, on the other hand, reflects either successful organizing of new units or, conversely, the decertification of existing units or shutdown of unionized facilities.

Strike activity. Our interviews with union organizers indicated that opposition to or fear of strikes is a significant issue in many clerical organizing campaigns. We hypothesize that the level of strike activity in a state will be negatively related to the percentage of clerical workers voting for the union because such activity can be 
Table 1. Independent Variables Used in the Regression Analysis.

\begin{tabular}{|c|c|c|c|c|}
\hline Variable & $\begin{array}{l}\text { Hypothesized } \\
\text { Sign of } \\
\text { Coefficient }\end{array}$ & $\begin{array}{l}\text { Sample } \\
\text { Proportion } \\
\text { or Mean }\end{array}$ & $\begin{array}{l}\text { Standard } \\
\text { Deviation }\end{array}$ & Source \\
\hline $\begin{array}{l}\text { LOCALS } \\
\text { Number of locals in state per } \\
\text { thousand employed, } 1979 .\end{array}$ & + & 0.597 & 0.225 & \multirow{3}{*}{$\begin{array}{l}\text { Number of locals for } 1977 \text { and } \\
1980 \text { from Gifford (1984-85, } \\
\text { Appendix B); number of locals } \\
\text { in } 1979 \text { estimated by linear inter- } \\
\text { polation. Employed persons by } \\
\text { state from U.S. BLS (1977-80). }\end{array}$} \\
\hline $\begin{array}{l}\text { CHANGE IN LOCALS } \\
\text { no. locals in } 1980 \\
\text { no. employed } 1980\end{array}$ & + & -0.056 & 0.036 & \\
\hline$-\frac{\text { no. locals in } 1977}{\text { no. employed in } 1977 .}$ & & & & \\
\hline PERCENT ORGANIZED & & & & \\
\hline $\begin{array}{l}\text { Percentage of workers organ- } \\
\text { ized in the state in which the } \\
\text { election is held, } 1979 \text {. }\end{array}$ & + & 27.769 & 7.666 & $\begin{array}{l}\text { Percent organized by state from } \\
\text { Troy and Sheflin ( } 1985, \\
\text { Table } 7.2) \text {. }\end{array}$ \\
\hline $\begin{array}{l}\text { CHANGE IN \% ORGANIZED } \\
\text { Percentage of workers organized } \\
\text { in } 1980 \text { minus the percentage } \\
\text { organized in } 1975 .\end{array}$ & + & -5.975 & 2.135 & \\
\hline $\begin{array}{l}\text { STRIKE ACTIVITY } \\
\text { Proportion of workers in state } \\
\text { who went on strike during } 1979 .\end{array}$ & - & 0.019 & 0.011 & U.S. BLS (1981a, Table 21). \\
\hline $\begin{array}{l}\text { EMPLOYMENT CHANGE } \\
\text { Index for the period } 1970-1978 \text {. }\end{array}$ & + & 1.236 & 0.244 & U.S. BLS (1981b, Table 2). \\
\hline $\begin{array}{l}\text { UNEMPLOYMENT RATE } \\
\text { For clerical workers, by state, } 1979 .\end{array}$ & - & 4.706 & 0.904 & U.S. BLS (1977-80). \\
\hline $\begin{array}{l}\text { WAGE RATIO } \\
\text { A weighted average of } 1979 \\
\text { median earnings of full-time } \\
\text { clerical workers and median } \\
\text { earnings of full-time sales work- } \\
\text { ers divided by a weighted aver- } \\
\text { age of median earnings of all } \\
\text { full-time male and all full-time } \\
\text { female workers. }\end{array}$ & - & 0.861 & 0.030 & $\begin{array}{l}\text { U.S. Bureau of the Census (1983, } \\
\text { Ch. D: "Detailed Population Char- } \\
\text { acteristics," Table 222). }\end{array}$ \\
\hline $\begin{array}{l}\text { STIPULATED } \\
1 \text { if stipulated election, } \\
0 \text { otherwise. }\end{array}$ & - & 0.789 & 0.408 & NLRB Tape. \\
\hline $\begin{array}{l}\text { ORDERED } \\
1 \text { if Board-ordered or Regional } \\
\text { director-ordered, } 0 \text { otherwise. }\end{array}$ & - & 0.162 & 0.369 & NLRB Tape. \\
\hline $\begin{array}{l}\text { DELAY } \\
\text { Between filing of petition and } \\
\text { election (in months). }\end{array}$ & - & 1.908 & 1.589 & NLRB Tape. \\
\hline $\begin{array}{l}\text { CLERICAL EMPLOYMENT RATIO } \\
\text { Clerical employment relative to } \\
\text { total employment, by industry. }\end{array}$ & - & 0.299 & 0.203 & $\begin{array}{l}\text { U.S. Bureau of the Census ( } 1984 \text {, } \\
\text { Part } 7 \text {-C, Table } 4) \text {. }\end{array}$ \\
\hline SIZE & - & 42.141 & 108.079 & NLRB Tape. \\
\hline VOTER TURNOUT & - & 0.910 & 0.116 & NLRB Tape. \\
\hline $\begin{array}{l}\text { MULTI-UNION } \\
1 \text { if more than one union in- } \\
\text { volved in the election, } 0 \text { other- } \\
\text { wise. }\end{array}$ & + & 0.029 & 0.168 & NLRB Tape. \\
\hline
\end{tabular}


expected to exacerbate these fears. At least one other study has investigated the impact of strike activity on NLRB election results, but in a somewhat different context. Maranto and Fiorito (1987) tested the impact of a specific union's strike activity on that union's likelihood of victory in a representation election. Although their hypothesis of a negative relationship is similar to ours and is generally supported by their empirical tests, our interest is focused on the level of strike activity in the state rather than a specific union's reputation.

Change in industry employment. An index of the change in employment in the relevant three-digit SIC industry over the eight-year period prior to the election is included to reflect the health of the industry. Given that clerical workers are largely unorganized, we postulate that they will be more inclined to favor unionization if employment in the industry is expanding. Where employment is declining, unionization might be viewed as hastening the decline by increasing labor costs. This variable is designed to capture in part the barrier to unionization posed by the fear of job loss noted by clerical organizers.

We should mention that this hypothesis is at odds with Seeber's (1983) hypothesis concerning union organizing in manufacturing in the 1973-76 period, although the negative relationship he hypothesized did not prove to be significant. Seeber's focus, however, was on production workers in manufacturing, among whom unionization was firmly established in the mid-1970s. Clerical workers can be expected to respond quite differently because unionization is less common in clerical occupations and therefore potentially more threatening in an industry with declining employment.

Unemployment. The unemployment rate for clerical workers in the state is included as one measure of economic conditions. Although those studies that have used unemployment as an independent variable have not established a significant relationship between that variable and the union victory rate (see Heneman and
Sandver 1983:533), we nevertheless hypothesize that a higher unemployment rate among clerical workers will discourage support for unions by increasing the fear of job loss.

Relative wages. Studies of the determinants of the voting behavior of individuals have found that a substantial proportion of the variance in voting behavior can be explained by employee satisfaction levels (Heneman and Sandver 1983:539). In election-level studies, the satisfaction of the employees is also likely to influence the outcome of a union election. Kochan (1979) has demonstrated that one factor affecting job satisfaction is the perceived equity in pay scales among different types of workers. This finding is consistent with the observation of clerical organizers that economic neglect is often a prime motivator for unionization.

Unfortunately, lack of data makes it impossible to construct a variable measuring the pay of clerical workers relative to other workers in the company in which the election is being held. Instead, we use state-level data to define a wage ratio variable that is the ratio of median clerical workers' earnings to the median earnings of all workers in the state. ${ }^{4}$ Higher levels of the wage ratio should lead to more job satisfaction among clerical workers and to lower union victory rates. Therefore, we hypothesize a negative relationship between the dependent variable and the wage ratio variable.

\section{Variables Related to Management Resistance of Unions}

Type of election. Heneman and Sandver (1983:551) urge researchers to maintain distinctions among consent, stipulated, regional director-ordered, and Boardordered elections in order to control for "differing conditions surrounding the elec-

\footnotetext{
4 The problem of not having data at the appropriate level of aggregation is not limited to this variable. It would be best to have data not only on company-specific relative wages but also on employment, unemployment, and unionization at the level of the appropriate local labor market rather than at the state level.
} 
tion and differing attitudes and behavior on the part of labor and management." Seeber and Cooke (1983) note a significant positive relationship between consent elections and the union victory rate. They hypothesize that a consent election indicates a lack of strong management resistance to the organizing campaign and employer satisfaction with the definition of the election unit.

As Cooke (1983:406) describes it, a stipulated election indicates that the employer "wants a hearing about unit determination and wants disputes over campaign activities and election outcomes to be resolved by the five-member Board." Cooke's statement is not totally accurate, because a stipulated election is like a consent election except that one of the parties (usually management) "reserve[s] the right to raise these issues after the election takes place" (Taylor and Witney 1979:225). Nonetheless, the employer's reservation of the right to challenge such issues as the scope of the unit, the eligibility of employees, the time and place of the election, and related matters indicates a more cautious, less cooperative attitude toward the election than would be expected of managers who accept a consent election. An employer who chooses a stipulated election rather than a consent election is therefore likely to be more aware of strategies to reduce the chance of a union victory and more likely to mount an active campaign against unionization. Given the report by organizers that union avoidance consultants are present in most clerical elections, the distinction between consent and stipulated elections is likely to be important.

On the other hand, consent elections reflect less disagreement than exists in regional director-ordered or Boardordered elections. A regional director- or Board-ordered election may occur if an appeal of election details is filed before the election takes place. Alternatively, a new election may be ordered if an unfair labor practice was committed that influenced the outcome of the original election. Because of the acrimony that would exist in either case, an ordered election is less likely to result in a union victory than a consent election.

We define two dummy variables to account for the differences among these types of elections. The first takes on a value of one for a stipulated election and the second takes on a value of one for a regional director-ordered or a Board-ordered election. The coefficients on these variables both reflect a contrast with consent elections, and therefore we hypothesize a negative relationship between each of these variables and the percent vote for the union.

Delay. Consistent with the opinions of the clerical organizers we interviewed, the relationship between the union victory rate and the delay from the filing of an election petition to the conduct of the election has been found to be consistently negative in those studies that included a delay variable (Heneman and Sandver 1983:544). Support for unions tends to erode with delay for two reasons: ${ }^{5}$ the elapsed time allows management to mount a campaign against the union, and, simultaneously, the enthusiasm and time commitment of the union organizing team (typically dominated by members of the work unit devoting personal time to organizing activity) tends to wane.

Clerical employment ratio. An employer's incentive to resist unionization depends on the impact that unionization is expected to have. Seeber (1983) suggests that the capital to labor ratio is important because the potential impact of unionization on cost increases with the ratio of labor costs to total costs. The capital to labor ratio is probably not as important a factor in management resistance to clerical worker organizing as it is in resistance to organizing efforts by production workers, however, because in many industries (including all of manufacturing) clerical workers account for a very low proportion of total employment. We therefore define a variable that measures the ratio of clerical employment in the in-

\footnotetext{
${ }^{5}$ These arguments are specific to delays after the filing of an election petition. Delays from the beginning of organizing to the filing of an election petition cannot be measured in the NLRB data.
} 
dustry to total employment in the industry. Ceteris paribus, the higher this ratio, the greater the incentive for management to resist unionization and the lower the expected pro-union vote.

\section{Miscellaneous Election and Bargaining Unit Characteristics}

Unit size. Unit size has been one of the most thoroughly investigated variables in prior research on NLRB election outcomes. Increases in the size of a unit are hypothesized to be associated with less cohesiveness among the employees and reduced employee communication, so that one might expect a negative relationship between unit size and the percentage of workers voting for union representation. Prior empirical studies have consistently found such a relationship (see Heneman and Sandver 1983:544). Following Cooke (1983), we introduce the unit size variable as $1 /$ sIzE, where SIZE represents the number of employees eligible to vote in the certification election.

Voter turnout. The few studies that have examined voter turnout in an election have found it to be negatively related to the union victory rate (Heneman and Sandver 1983:544). The explanation hypothesized for this result is that marginally interested voters tend to support the status quo, and therefore their participation reduces the union's chances of winning. This explanation accords with the accepted wisdom among management consultants, who typically advocate an aggressive "get-out-the-vote" campaign to improve the odds for a defeat of the union (Gagala 1983:72-73).

Number of unions. Some elections involve more than one union contending for votes. The presence of more than one union organizing campaign is likely to increase employee awareness and interest and increase the proportion of employees voting for union representation. Furthermore, because unions vary significantly in style, militance, and organizing strategy, with more than one option the individual worker is more likely to find a union choice that matches his or her preferences.
Multi-union dummy variables have been used in only a few studies of election outcomes (see, for example, Delaney 1981; Becker and Miller 1981). In spite of statistically insignificant results in prior studies, Heneman and Sandver (1983:552) urge researchers to incorporate variables that distinguish between single union and multi-union elections because "interunion comparisons and rivalry . . may play a significant role in influencing the results of multiunion elections."

\section{Data and Results}

We chose to analyze NLRB elections held during 1979 because it was the only year for which we could get detailed data for all of our variables. During 1979 there were 735 conclusive NLRB elections held in units consisting of office, clerical, and other white-collar workers. ${ }^{6}$ A number of these elections are not included in our empirical analysis. We have deleted 70 decertification elections, 19 employerpetitioned elections, one expedited election, 11 elections held outside the United States, and 12 observations because of missing or bad data. ${ }^{7}$ Our final sample consists of 622 elections, 54.7 percent of which were won by a union. 8

Table 2 contains the results obtained

\footnotetext{
${ }^{6}$ Conclusive elections are those in which a decision is made-that is, in which one of the alternatives on the ballot receives a majority of the votes and no run-off election is necessars. If no alternative receives a majority, a run-off is held between the two highest vote-receiving alternatives. The XLRB data set does not include the first inconclusive election results. If a run-off is necessary, only the results from the run-off election are available.

' We are interested in elections in which the union has conducted a standard organizing campaign and has voluntarily filed for an election. Employerpetitioned and expedited elections occur under unusual circumstances, typically involving organizational picketing and sometimes violations of the N.L.R.A. section 8.b.7 restrictions (Mvers and Twomey 1975:265-66; Taylor and Witney 1979:299-300, 464-65). We would expect these elections to turn out quite differently from those in which the union has requested an election, and thus we have excluded them from our sample.

${ }^{8} \mathrm{By}$ comparison, unions had a win rate of 41.6 percent in elections held among production workers in 1979.
} 
Table 2. Determinants of Election Outcomes for Private Sector Clerical Workers, 1979.

\begin{tabular}{|c|c|c|c|c|}
\hline \multirow[b]{2}{*}{ Independent Variable } & \multicolumn{4}{|c|}{$\begin{array}{c}\text { Dependent Variable: Percent Vote for Union Representation } \\
\text { (standard error in parentheses) }\end{array}$} \\
\hline & (1) & (2) & (3) & (4) \\
\hline$\overline{\text { LOCALS }}$ & $\begin{array}{l}0.144^{* * *} \\
(0.069)\end{array}$ & $\begin{array}{l}0.127 * * \\
(0.075)\end{array}$ & $\begin{array}{l}0.129 * * \\
(0.069)\end{array}$ & - \\
\hline CHANGE IN LOCALS & $\begin{array}{l}0.807 * * * \\
(0.345)\end{array}$ & $\begin{array}{l}0.666^{* *} \\
(0.335)\end{array}$ & $\begin{array}{l}0.763^{* *} \\
(0.344)\end{array}$ & - \\
\hline PERCENT ORGANIZED & - & - & - & $\begin{array}{l}0.004^{* *} \\
(0.002)\end{array}$ \\
\hline CHANGE IN $\%$ ORGANIZED & - & - & - & $\begin{array}{l}0.010^{*} \\
(0.007)\end{array}$ \\
\hline \multirow[t]{2}{*}{ STRIKE ACTIVITY (a) } & $\begin{array}{l}-3.737 * * \\
(1.613)\end{array}$ & - & $\begin{array}{c}-3.381^{* *} \\
(1.614)\end{array}$ & $\begin{array}{r}-1.973^{*} \\
(1.332)\end{array}$ \\
\hline & - & $\begin{array}{l}-3.740^{* *} \\
(2.155)\end{array}$ & - & - \\
\hline EMPLOYMENT CHANGE INDEX & $\begin{array}{l}0.076^{* *} \\
(0.045)\end{array}$ & $\begin{array}{c}0.071^{*} \\
(0.045)\end{array}$ & $\begin{array}{c}0.074^{*} \\
(0.045)\end{array}$ & $\begin{array}{r}0.062^{*} \\
(0.045)\end{array}$ \\
\hline UNEMPLOYMENT RATE & $\begin{array}{r}-0.002 \\
(0.013)\end{array}$ & $\begin{array}{r}-0.006 \\
(0.013)\end{array}$ & $\begin{array}{r}-0.004 \\
(0.013)\end{array}$ & $\begin{array}{r}-0.015 \\
(0.014)\end{array}$ \\
\hline WAGE RATIO & $\begin{array}{r}-0.445 \\
(0.445)\end{array}$ & $\begin{array}{c}-0.459 \\
(0.480)\end{array}$ & $\begin{array}{r}-0.424 \\
(0.443)\end{array}$ & $\begin{array}{r}-0.116 \\
(0.566)\end{array}$ \\
\hline STIPULATED & $\begin{array}{r}-0.082^{*} \\
(0.051)\end{array}$ & $\begin{array}{c}-0.081 * \\
(0.051)\end{array}$ & $\begin{array}{c}-0.079^{*} \\
(0.051)\end{array}$ & $\begin{array}{c}-0.069^{*} \\
(0.051)\end{array}$ \\
\hline ORDERED & $\begin{array}{c}-0.070 \\
(0.058)\end{array}$ & $\begin{array}{c}-0.076^{*} \\
(0.058)\end{array}$ & $\begin{array}{c}-0.074 \\
(0.058)\end{array}$ & $\begin{array}{c}-0.064 \\
(0.058)\end{array}$ \\
\hline DELAY & $\begin{array}{c}0.006 \\
(0.007)\end{array}$ & $\begin{array}{c}0.006 \\
(0.007)\end{array}$ & $\begin{array}{c}0.006 \\
(0.007)\end{array}$ & $\begin{array}{c}0.006 \\
(0.007)\end{array}$ \\
\hline CLERICAL EMPLOYMENT RATIO & $\begin{array}{r}-0.087 * \\
(0.054)\end{array}$ & $\begin{array}{r}-0.082^{*} \\
(0.054)\end{array}$ & $\begin{array}{r}-0.083^{*} \\
(0.054)\end{array}$ & $\begin{array}{r}-0.075^{*} \\
(0.054)\end{array}$ \\
\hline 1/SIZE & $\begin{array}{l}0.7411^{* * *} \\
(0.099)\end{array}$ & $\begin{array}{l}0.759^{* * *} \\
(0.099)\end{array}$ & $\begin{array}{l}0.761^{* * *} \\
(0.099)\end{array}$ & $\begin{array}{l}0.752 * * * \\
(0.099)\end{array}$ \\
\hline VOTER TURNOUT & $\begin{array}{c}-0.031 \\
(0.096)\end{array}$ & $\begin{array}{c}-0.024 \\
(0.096)\end{array}$ & $\begin{array}{c}-0.022 \\
(0.096)\end{array}$ & $\begin{array}{c}-0.021 \\
(0.096)\end{array}$ \\
\hline MULTI-UNION & - & $\begin{array}{l}0.154^{* * *} \\
(0.065)\end{array}$ & $\begin{array}{c}0.151^{* *} \\
(0.065)\end{array}$ & $\begin{array}{l}0.156^{* * *} \\
(0.065)\end{array}$ \\
\hline Intercept & 0.931 & 0.956 & 0.909 & 0.664 \\
\hline No. of Observations & 622 & 622 & 622 & 622 \\
\hline $\mathrm{R}^{2}$ & 0.105 & 0.111 & 0.113 & 0.109 \\
\hline $\mathbf{F}$ & 5.959 & 5.831 & 5.949 & 5.735 \\
\hline
\end{tabular}

* Significant at the .10 level; ** significant at the .05 level; ${ }^{* * *}$ significant at the .01 level (one-tailed tests).

from ordinary least squares estimation of four specifications of the model. In all cases the dependent variable is defined as the number of votes for union representation divided by the total number of votes. The multi-union dummy variable is excluded from specification (1) but included in specifications (2), (3), and (4). The only elections included on the NLRB tape are conclusive elections. In cases of a first election involving two unions resulting in a run-off election involving only one of the unions, the multi-union dummy variable takes on a value of zero, indicating the presence of only one union in the actual conclusive election included in our data set. The fact that there was at one time more than one union vying for employee support cannot be taken into account in our multi-union variable. Be- 
cause biases may arise if this dummy variable does not accurately account for the number of unions that are or were candidates in the election, we present a specification that excludes this variable. ${ }^{9}$ As is readily apparent from the results reported in Table 2 , the presence of more than one union vying for support in an election is a significant factor in increasing the proportion of employees who vote for union representation, but the remaining coefficients are not affected when the multi-union dummy variable is deleted.

Specifications (1), (3), and (4) employ the strike variable that measures the proportion of workers in the state who went on strike during 1979. It could be argued that this measure does not accurately capture the perceived strike activity for those elections held early in 1979 . Because of our particular interest in clerical workers' fear of strikes, we define a second strike variable for inclusion in specification (2): the average of strike activity in 1978 and 1979 if the election was held in the first six months of 1979 , and simply strike activity in 1979 if the election was held in the last six months of 1979.

Specifications (1), (2), and (3) use the variables on the number of locals to measure unionization levels. Specification (4) differs from the other specifications in the use of the more conventional measure of unionization level - percentage of workers organized in the state in which the election was held.

An examination of Table 2 shows that, except for the delay variable, the signs of the coefficients are those expected. Because of our strong a priori ideas on the signs of the coefficients, the hypothesis tests for the statistical significance of the individual coefficients are all performed as one-tailed tests. The F-ratio indicates that a statistically significant relationship exists between our set of independent variables and the percent vote for union representation.

\footnotetext{
${ }^{9}$ We have identified only nine elections in which this inaccuracy could have occurred.
}

\section{Variables Related to Worker Interest in Unionization}

The coefficients on the six variables reflecting worker interest in unionization are all of the hypothesized sign. In general, these variables contribute significantly to the explanatory power of the model. Both the number of locals per thousand employed in the state and the change in the number of locals per thousand employed affect the percent vote positively and significantly. The same is true when the variables measuring the percent organized are used. These results are consistent with our hypotheses and indicate that the voting behavior of clerical workers is quite sensitive to the vitality of the labor movement.

Our hypothesis regarding the intimidating effect of strike activity in the state is also supported by the evidence. Higher levels of strike activity lead to a lower proportion of votes for union representation. The health of the industry also has a significant influence on the percent vote. Clerical workers apparently do view unionization as being threatening in a declining industry.

The coefficient on the unemployment rate variable is small in magnitude and not statistically significant. This result is consistent with the findings of other studies, and suggests that clerical workers are no more influenced in their voting behavior by the unemployment rate than are production workers.

The final variable hypothesized to influence the worker's perceived benefit from a union is the wage ratio, which measures median clerical earnings relative to median earnings of all workers. The coefficient reflects the hypothesized negative relationship, but it is neither statistically significant nor large in magnitude. This result is not surprising, because what should really influence the voting behavior of clerical workers is their perception of the equity between their wages and the wages of non-clericals employed by the same company. Our wage ratio variable measures relative earnings at the state level and is therefore only a rough proxy 
for what we really would like to measure. In addition, at the state level this variable exhibits considerably less variation than would an election-level wage ratio.

\section{Variables Related to Management Resistance to Unions}

With one important exception, the coefficients of the variables related to management resistance to unions have the expected sign and are significant. Stipulated elections and regional or Boardordered elections result in a lower proportion of workers voting for representation than in consent elections. The coefficient is larger in magnitude, and more often statistically significant, for the stipulated than for the ordered elections.

The coefficient on the delay variable is the only one that does not have the hypothesized sign. ${ }^{10}$ The magnitude of this coefficient is very small, however, and not significantly different from zero. This result may be a reflection of the cautious nature of clerical workers. In clerical units, there is typically a much longer period of organizing activity prior to the petitioning for a vote than in other types of units. In addition, an examination of the delay variable indicates that the average delay is shorter in clerical elections than in elections among other types of workers (1.91 months versus 2.22 months) and the variation in delay is also smaller (a standard deviation of 1.59 months versus 2.84 months). Thus, a delay appears not to have much of an impact on the decisions clerical workers made during the long organizing process.

The coefficient on the clerical employment ratio variable is negative and statistically significant, supporting our hypothesis that higher levels of clerical employment relative to total employment provide a greater incentive to management to resist

\footnotetext{
${ }^{10}$ Concern about possible multicollinearity between the delay variable and the election-type dummy variables led to a re-estimation with the election-type variables excluded. The sign, magnitude, and lack of statistical significance of the coefficient on the delay variable were unaffected.
}

unionization and therefore result in a lower percent vote. The magnitude of the coefficient is small, however.

\section{Miscellaneous Election and Bargaining Unit Characteristics}

Two of the miscellaneous election and bargaining unit variables have a significant influence on the percent vote for union representation. The coefficient on the 1/SIzE variable supports the hypothesis of a negative relationship between unit size and percent vote for the union. The multi-union variable also affects the percent vote significantly and positively as hypothesized. Although the coefficient for the voter turnout variable has the hypothesized negative sign, the relationship is not significant.

\section{Importance of Organizer Interviews}

Because ours is the first econometric study of NLRB certification elections that generates hypotheses from interviews with union organizers, it is appropriate to evaluate the influence of the interview results on the analysis. Although several previous studies have tested the impact of the level of unionization on election results, none have included variables measuring the change in level of unionization. Our interviews convinced us that for clerical workers a key issue considered in union representation elections is the vitality of the labor movement. We subsequently defined two variables intended to capture vitality, as described above. The statistically significant relationship between these variables and the percent vote for a union lends support to the observations of the organizers.

Also suggested to us by the interviews was the strike variable, which also proves to be significant. Specifically, strike activity in the local area was viewed as an inhibiting factor in clerical organizing campaigns. Although a similar variable has been included in one prior study, it was defined based on the specific union's involvement in large strikes whereas our variable is geographically defined. 
Several of the variables we included were suggested to us not only by our interview results, but also by prior research on NLRB certification elections: level of unionization, relative wages, type of election, delay, and clerical employment ratio. In the case of the delay variable, the interviews helped us explain why our results differ from those of other studies. As noted above, delay after the filing of the election petition probably has less impact in clerical campaigns than in campaigns among production workers because the organizing process before filing is usually slow and methodical.

One variable suggested to us by the interviews, change in industry employment, has been tested in a prior study, but with a reverse hypothesis. The positive relationship we predicted (because the union representatives we interviewed saw job loss as a negative influence on attempts to organize clericals) is substantiated by the econometric results.

In short, we believe that the interviews were useful to us both for developing hypotheses and for explaining the results of our econometric tests. We strongly encourage other researchers interested in union organizing efforts to conduct interviews with practitioners from labor organizations, management, governmental agencies, and consulting firms prior to statistical analysis of the NLRB data.

\section{Conclusions}

The outcome of union organizing efforts among private sector clerical workers will influence the future makeup, focus, and vitality of the U.S. labor movement. In this paper we have investigated some of the factors that will help determine whether these efforts are successful. Based on interviews with union organizers and an analysis of NLRB elections involving clerical units, we have identified several variables that have a significant impact on the willingness of clerical workers to vote for unionization.

We believe that our most interesting results relate to environmental factors influencing clerical workers' support for unionization. Specifically, clerical workers are more likely to vote for union representation in states where the unions have a strong presence, particularly if the union movement is expanding. Strike activity in a state, however, negatively affects clerical union representation votes. Recent initiatives by some unions to pursue non-strike alternatives (ranging from increased cooperation with management via employee involvement plans to "in-plant" strategies such as work slowdowns) may actually help create an environment more conducive to clerical organizing. Finally, our results indicate that clerical workers are more likely to vote for a union if they work in an industry with increasing employment, a positive note for those unions hoping to organize in the service sector.

Most of our results parallel those of studies of NLRB elections for non-clerical units. The negative relationship between the size of the unit and the pro-union vote indicates that clerical organizers should not ignore small units. Also, as expected, management resistance significantly affects election results, as indicated by our findings regarding stipulated and ordered elections. We have provided further evidence of management effectiveness in this regard by demonstrating a significant negative relationship between employee support for unionization and the clerical share of employment in an industry. Management has a greater incentive to resist clerical unions in clerical-intensive industries, and is more effective in these efforts, than in other industries.

Our findings on the determinants of clerical election outcomes differ from the findings of similar studies covering all NLRB elections in only one important respect: whereas previous studies have demonstrated that election delay has a significant negative impact on union organizing success, we have found no such relationship in clerical units. Although further investigation of this conclusion is warranted, we believe that it is consistent with the relatively slow organizing process typical in clerical campaigns.

A more complete assessment of the potential for organizing clerical workers will 
require additional research on clerical attitudes toward unions, and on electionspecific details such as relative pay within the firm, union organizing strategies, and management resistance strategies. We believe that our focus on environmental factors is an appropriate starting point for an understanding of the dynamics of clerical worker organizing. Furthermore, we hope that our research approach, combining interviews with econometric analysis of secondary data, will prove useful to researchers interested in analyzing other aspects of NLRB union representation elections.

\section{REFERENCES}

Antos, Joseph R., Mark Chandler, and Wesley Mellow

1980 "Sex Differences in Union Membership." Industrial and Labor Relations Review, Vol. 33, No. 2 (January), pp. 162-69.

Becker, Brian E., and Richard U. Miller

1981 "Patterns and Determinants of Union Growth in the Hospital Industry." Journal of Labor Research, Vol. 2, No. 2, pp. 309-28.

Bureau of National Affairs

1984 "Conference Told Union Organizing Must Focus on Women's Issues." White Collar Report, July 18, pp. 77-78.

Cooke, William N.

1983 "Determinants of the Outcomes of Union Certification Elections." Industrial and Labor Relations Review, Vol. 36, No. 3 (April), pp. 402-14.

Delaney, John Thomas

1981 "Union Success in Hospital Representation Elections." Industrial Relations, Vol. 20, No. 2 (Spring), pp. 149-61.

Farber, Henry $\mathrm{S}$.

1985 "The Extent of Unionization in the United States." In Thomas A. Kochan, ed., Challenges and Choices Facing American Labor. Cambridge, Mass.: MIT Press.

Fiorito, Jack, and Charles S. Greer

1982 "Determinants of U.S. Unionism: Past Research and Future Needs." Industrial Relations, Vol. 21, No. 1 (Winter), pp. 1-32.

Gagala, Ken

1983 Union Organizing and Staying Organizing Reston, Va.: Reston Publishing Co.

Gifford, Courtney D., ed.

1984- Directory of U.S. Labor Organizations. Washing-

85 ton, D.C.: Bureau of National Affairs.

Heneman, Herbert G., and Marcus H. Sandver

1983 "Predicting the Outcome of Union Certification Elections: A Review of the Literature." Industrial and Labor Relations Review, Vol. 36, No. 4 (July), pp. 537-59.

Hill, Ann

1985 Service Employees International Union, District 925 Regional Director, Cleveland office. Telephone interview, March 4

Hurd, Richard W.

1986 "Bottom-Up Organizing: HERE in New Haven and Boston." Labor Research Review, Vol. 8 (Spring), pp. 5-20.
Kazel, Ron

1986 United Food and Commercial Workers Union, Region 17, Assistant Director, Telephone interview, March 4.

Kochan, Thomas A.

1979 "How American Workers View Labor Unions." Monthly Labor Review, Vol. 102, No. 4 (April), pp. 23-31.

Kushner, Julie

1986 United Automobile Workers, District 65 Vice President. Personal interview, New York City, May 1.

Ladin, Bonnie

1985 Service Employees International Union, District 925, Organizing Director. Telephone interview, March 11.

Lawler, John, and Greg Hundley

1983 "Determinants of Certification and Decertification Activity." Industrial Relations, Vol. 22, No. 3 (Fall), pp. 335-48.

Lechow, Karl

1985 Hotel Employees and Restaurant Employees International Union, Assistant Organizing Director. Personal interview, Washington, D.C., August 13.

Maranto, Cheryl L., and Jack Fiorito

1987 "The Effect of Union Characteristics on the Outcome of NLRB Certification Elections." Industrial and Labor Relations Review, Vol. 40, No. 2 (January), pp. 225-40.

Margolies, Ken

1986 Communications Workers of America, Organizing Director. Personal interview, Washington, D.C., January 27.

Myers, A. Howard, and David Twomey

1975 Labor Law and Legislation. Cincinnati: SouthWestern Publishing Co.

Nussbaum, Karen

1986 Service Employees International Lnion, District 925, President. Personal interview, Whitefield, N.H., October 3.

Rahke, Barbara

1986 United Automobile Workers, Technical Office and Professional Division, Director of Organizing. Personal interview, Cambridge, Mass., January 21.

Saporta, Vicki

1986 International Brotherhood of Teamsters, Organizing Director. Personal interview, Washington, D.C., January 28. 


\section{Schaffer, Cheryl}

1985 Service Employees International Union, District 925, Regional Director, Boston office. Personal interview, Boston, February 1.

Seeber, Ronald $L$.

1983 "Union Organizing in Manufacturing, 1973-1976." In David B. Lipsky and Joel M. Douglas, eds., Advances in Industrial and Labor Relations, Vol. 1. Greenwich, Conn.: JAI Press, pp. 1-30.

Seeber, Ronald L., and William N. Cooke

1983 "The Decline in Union Success in NLRB Representation Elections." Industrial Relations, Vol. 22, No. 1 (Winter), pp. 34-44.

Stephen, Paula E., and Bruce E. Kaufman

1987 "Factors Leading to a Decline in the Union Win Rates: 1973-81." Proceedings of the Thirty-Ninth Annual Meeting (December 28-30, 1986). IRRA Series. Madison, Wis.: Industrial Relations Research Association.
Taylor, Benjamin, and Fred Witney

1979 Labor Relations Law, 3d Edition. Englewood Cliffs, N.J.: Prentice-Hall.

Troy, Leo, and Neil Sheflin

1985 U.S. Union Sourcebook, 1st Edition. West Orange, N.J.: Industrial Relations Data and Information Services.

U.S. Bureau of the Census

19841980 Census of Population by Industry. Washington, D.C.: GPO.

19831980 Census of Population, Vol. 1: Characteristics of the Population. Washington, D.C.: GPO.

U.S. Bureau of Labor Statistics

1981a Analysis of Work Stoppages, 1979. Washington, D.C.: GPO.

$1981 \mathrm{~b}$ The National Industry-Occupation Employment Matrix, 1970, 1978, and Projected 1990, Volume II. Table 2. Washington, D.C.: GPO. 1977- Geographic Profile of Employment and Unemploy80 ment. Washington, D.C.: GPO.

U.S. National Labor Relations Board

1985 Data tape, election statistics, 1979. 